\title{
Possible modes of dissemination of the amphibian chytrid Batrachochytrium dendrobatidis in the environment
}

\author{
Megan L. Johnson, Richard Speare* \\ Amphibian Diseases Group, School of Public Health and Tropical Medicine and Rainforest CRC, James Cook University, \\ Townsville, Queensland 4811, Australia
}

\begin{abstract}
Amphibian chytridiomycosis caused by Batrachochytrium dendrobatidis has spread at an alarming rate over large distances throughout sensitive frog populations in eastern Australia, Central America and New Zealand. Infected amphibians and contaminated water are implicated in translocation, but other vectors are unknown. Through in vitro studies we show that potential means of translocation may be moist soil and bird feathers. $B$. dendrobatidis survived for up to 3 mo in sterile, moist river sand with no other nutrients added. $B$. dendrobatidis attached to and grew on sterile feathers and were able to be transported by feathers to establish new cultures in media, surviving between 1 and $3 \mathrm{~h}$ of drying between transfers. If these in vitro results are valid in the natural environment, the findings raise the possibilities that $B$. dendrobatidis may be translocated by movement of moist river sand and that birds may carry the amphibian chytrid between frog habitats. However, further studies using sand and feathers containing normal microflora are essential.
\end{abstract}

KEY WORDS: Batrachochytrium dendrobatidis $\cdot$ Chytridiomycosis · Amphibian chytrid · Translocation · Feathers · Soil

\section{INTRODUCTION}

The chytrid fungus Batrachochytrium dendrobatidis is highly pathogenic to amphibians. It has been identified as the cause of death of amphibians in many countries and regions, including Australia, New Zealand, Spain, Germany, Central America and North America (Berger et al. 1998, Pessier et al. 1999, Mutschmann et al. 2000, Bosch et al. 2001, Waldman et al. 2001). $B$. dendrobatidis is a member of the phylum Chytridiomycota. Representatives of this phylum are ubiquitous, heterotrophic fungi found primarily in water and soil, and contribute significantly to the initial degradation of plant detritus, chitin and keratin (Barr 1980, El-Hissy 1994). B. dendrobatidis is hypothesised to be a saprophytic organism, able to live in the environment in the absence of an amphibian host (Speare et al. 2001). However, until recently questions persisted on the survival of this organism outside of a suit- able host (Longcore et al. 1999). A previous study showed that the chytrid fungus can survive without a host and remain infectious for between 3 and $6 \mathrm{wk}$ in sterile aquatic environments (Johnson \& Speare 2003). It was also shown that the fungus attached itself to plant debris and microorganisms within the sterile environment; however, no sign of degradation of these bodies was apparent. The effects of other microscopic competitors such as bacteria and other fungi on the chytrid fungus are unknown.

The sudden decline of amphibian species due to Batrachochytrium dendrobatidis in a number of countries around the world is the subject of much debate. There is increasing evidence that this organism was introduced into naïve populations of amphibians and caused sudden, mass mortalities (Berger et al. 1998, 1999). However, ongoing investigations into its origins and historical presence may elucidate whether it is endemic or has been introduced. If the latter is true, 
the methods of dissemination of $B$. dendrobatidis are particularly important in understanding its life cycle and attempting to control the spread of this highly pathogenic organism. It is currently hypothesised that the fungus is spread by its own movement through water bodies, via surface water during precipitation, or by the activity of individual infected amphibians (Speare et al. 2001). It has also been postulated that the fungus may be transported by one or more vectors such as waterbirds, migratory fish, or by the introduced cane toad Bufo marinus (Laurance et al. 1997, Johnson et al. 2003). The growth of other members of the phylum Chytridiomycota in soil also presents an important possibility for the chytrid organism to be spread via the movement of soil such as in extraction industries, in plant nursery products, or in contaminated soil on vehicles or footwear of hikers.

In this study, Batrachochytrium dendrobatidis was inoculated into 2 types of sterile, moist soil in order to determine whether it could grow in moist soil in the absence of an amphibian host. The $\mathrm{pH}$ tolerance of this organism was also studied to determine if this were a factor that might influence survival in different soils. The growth of $B$. dendrobatidis on feathers, its ability to be transferred by bird feathers, and its survival after various periods of desiccation whilst attached to the feathers were studied in order to determine whether bird feathers might be a possible means of transport of the chytrid fungus between water bodies.

\section{MATERIALS AND METHODS}

Two strains of Batrachochytrium dendrobatidis were obtained from the CSIRO Australian Animal Health Laboratory (AAHL) (Geelong, Victoria). Strain 981469/10 was isolated from a captive juvenile Limnodynastes dumerilii and Strain 98-1810/3 was obtained from a wild adult of Nyctimystes dayi originally from Tully, Queensland. Cultures were maintained in vitro by serial passage using $10 \mathrm{ml}$ of TGhL liquid media (16 $\mathrm{g}$ tryptone, $2 \mathrm{~g}$ gelatin hydrolysate, $4 \mathrm{~g}$ lactose in $1000 \mathrm{ml}$ deionised water) in culture flasks or petri dishes at $23^{\circ} \mathrm{C}$ in a humidified incubator. Cultures were observed under an inverted Olympus microscope (Olympus Optical Company). Down feathers were collected from both domestic chickens and ducks, and were sterilised at $121^{\circ} \mathrm{C}$ for $15 \mathrm{~min}$. Potting mix was purchased from a plant nursery, coarse sand was collected from a creek in Townsville, North Queensland, and both were sterilised as above. Sterilised soil and feathers had to be used since viability of $B$. dendrobatidis cannot be demonstrated when other microorganisms are present owing to overgrowth in the media.
In Expt 1, small chicken feathers of uniform size were placed into petri dishes containing $9 \mathrm{ml}$ of TGhL media. For each strain, a $1 \mathrm{ml}$ aliquot from a $4 \mathrm{~d}$ old culture of Batrachochytrium dendrobatidis was inoculated into these dishes and the dishes were then placed at $23^{\circ} \mathrm{C}$ for 4 to $5 \mathrm{~d}$. These cultures were observed under a microscope for attachment and growth of zoosporangia on the feathers. Feathers were then removed using sterile forceps and placed into sterile petri dishes within a laminar flow hood. Feathers were left to dry for $5 \mathrm{~min}, 10 \mathrm{~min}, 30 \mathrm{~min}, 1 \mathrm{~h}, 2 \mathrm{~h}$, and $3 \mathrm{~h}$. They were subsequently placed into new petri dishes containing $10 \mathrm{ml}$ TGhL media and incubated at $23^{\circ} \mathrm{C}$. Observations were then made over a period of $4 \mathrm{wk}$ in order to discern any growth or activity, the latter manifested by swimming zoospores or actively moving zoospores inside a zoosporangium. This experiment was repeated using duck feathers with an additional drying time of $2.5 \mathrm{~h}$. Expt 2 tested the ability of feathers to transport the fungus after only short periods in contact with active $B$. dendrobatidis zoospores. Thirty $\mathrm{ml}$ of $4 \mathrm{~d}$ old culture of each strain was centrifuged at $2500 \mathrm{rpm}(980 \times g)$ for $5 \mathrm{~min}$ in order to pellet zoosporangia. The supernatant containing zoospores only was then pipetted into petri dishes. Feathers were placed in these cultures for $1 \mathrm{~min}$, then removed using sterile forceps, placed in empty petri dishes and left to dry for $1 \mathrm{~min}, 5 \mathrm{~min}, 10 \mathrm{~min}, 30 \mathrm{~min}, 1 \mathrm{~h}, 2 \mathrm{~h}$, and $3 \mathrm{~h}$. The feathers were then transferred into TGhL media in new petri dishes and growth was observed for a period of $4 \mathrm{wk}$. This experiment was repeated.

The next series of experiments tested the $\mathrm{pH}$ range tolerated by the chytrid fungus and then tested its survival in 2 different types of soil with different $\mathrm{pH}$. In Expt 3, the $\mathrm{pH}$ of the TGhL media was adjusted using either $\mathrm{NaOH}$ or $\mathrm{HCl}$ to provide a broad range of $\mathrm{pH}$, from $\mathrm{pH} 3$ through to $\mathrm{pH} 10$ (see Table 4). Buffering agents were not added as Batrachochytrium dendrobatidis has been shown to be sensitive to high salt levels in culture (Longcore et al. 1999). For each strain, $1 \mathrm{ml}$ of $4 \mathrm{~d}$ old culture was added to $9 \mathrm{ml}$ TGhL media at each $\mathrm{pH}$ and incubated at $23^{\circ} \mathrm{C}$. Observations were continued for a period of up to $7 \mathrm{wk}$. In some flasks the presence of growth was difficult to determine. Therefore small aliquots were removed from these flasks, inoculated into normal $\mathrm{pH}$ TGhL media (pH 6.7), incubated at $23^{\circ} \mathrm{C}$, and observations recorded of any subsequent growth and activity. Expt 4 was carried out with 2 types of soil: commercially available potting mix and coarse sand collected from a creek bed. Potting mix was tested because pot plants and soil are transported in the nursery trade. This therefore represents a possible opportunity for dissemination of chytrids, either by amphibians inhabiting the soil, or by soil contaminated with the fungus. Coarse sand from a creek bed 
grew to produce active zoospores within $3 \mathrm{~d}_{\text {; }}$ however, the period to overgrowth in the culture flasks by both strains was delayed by approximately 1 to $2 \mathrm{~d}$ when compared with cultures grown at $\mathrm{pH} 6$ to 7.5. Within this range of $\mathrm{pH}$, growth of both strains appeared as normal, with no delay period in establishment of the growth cycle. In cultures of Strain 981810/3 at pH 9 and 10 some active zoospores were observed within the first $3 \mathrm{~d}$; however, all activity had ceased by Day 7. No activity was observed at $\mathrm{pH} 10$ for Strain 98-1469/10 at any time; however, some slight activity was observed at $\mathrm{pH} 9$ within the first $7 \mathrm{~d}$. Inoculation into normal $\mathrm{pH}$ media showed that both strains remained viable even when activity and further growth was not apparent. Strain 981810/3 showed growth and activity when inoculated into normal $\mathrm{pH}$ TGhL media even after $1 \mathrm{wk}$ in media at pH 9 and 10. Strain 98-1469/10 showed growth and activity in normal $\mathrm{pH}$ TGhL media after 2 wk at $\mathrm{pH} 9$ and 10.

\section{Soil experiment}

Expt 4. Batrachochytrium dendrobatidis inoculated into a sterile mixture of potting mix and water did not survive. No growth of zoosporangia or activity by zoospores of either strain was observed in the flasks. Aliquots removed weekly and inoculated into TGhL media showed no growth of the fungus (Table 4). The $\mathrm{pH}$ of potting mix was measured according to a recommended method (Trigiano et al. 2003) and was found to be 4.1. The lack of growth in this $\mathrm{pH}$ mixture agreed with the results from the $\mathrm{pH}$ experiments. Growth for both strains in the sterile, wet creek bed sand was highly successful (Table 4). Weekly aliquots removed from the initial sand mixture and inoculated into TGhL media showed continuous growth of zoosporangia and active zoospores for $12 \mathrm{wk}$, after which the experiment was terminated. The $\mathrm{pH}$ of creek bed sand, measured as described above, was $\mathrm{pH}$ 5.8, a suitable $\mathrm{pH}$ for the chytrid fungus. The $\mathrm{pH}$ of sterile water alone was measured at 5.6, and survival in this medium was limited to $2 \mathrm{wk}$.

Table 4. Period of survival of Batrachochytrium dendrobatidis in 2 different sterile moist soils (Expt 4). Experiment terminated at $12 \mathrm{wk}$

\begin{tabular}{|lccc|}
\hline Medium & $\mathrm{pH}$ & $\begin{array}{c}\text { Strain } \\
98-1810 / 3\end{array}$ & $\begin{array}{c}\text { Strain } \\
98-1469 / 10\end{array}$ \\
\hline Commercial potting mix & 4.1 & $\mathrm{Nil}$ & $\mathrm{Nil}$ \\
Creek bed sand & 5.8 & $12 \mathrm{wk}$ & $12 \mathrm{wk}$ \\
Sterile water & 5.6 & $2 \mathrm{wk}$ & $2 \mathrm{wk}$ \\
\hline
\end{tabular}

\section{DISCUSSION}

This study demonstrated that zoospores of Batrachochytrium dendrobatidis will associate with feathers and if given sufficient time they will form attached zoosporangia. It was observed that the time of contact required for zoospores to become associated with feathers was brief; 1 min contact by feathers with active zoospores sufficed in our experiments. It may be that transport is only limited by the time it takes water to become associated with the feathers of a water bird. Mitchell \& Deacon (1986) observed that zoospores of various Chytridiomycetes were found attached to chitin within $3 \mathrm{~min}$ of adding the substrate to a suspension of zoospores. In addition, they noted that zoospores also exhibited a selective preference for suitable substrates on which they could grow.

This study showed that when zoospores only were transported, survival out of media was shorter than when zoosporangia attached to feathers were transported. For both strains in this study, growth of chytrids was observed after the 'host' spent 1 min in media containing zoospores and up to $1 \mathrm{~h}$ out of media; however, no growth was observed after $2 \mathrm{~h}$ out of water. If feathers remained in media until zoosporangia had developed, transport and survival of Batrachochytrium dendrobatidis after various drying periods was considerably longer. Strain 98-1810/3 survived transport by feathers and an intervening period out of media of 2 h. However, growth of Strain 98-1469/10 was not observed after this period. Attachment to duck feathers increased the survivability of $B$. dendrobatidis after longer drying periods. Transport of Strain 98-1810/3 was observed after $2.5 \mathrm{~h}$ drying. Even after $3 \mathrm{~h}$ drying, the duck feathers transported Strain 98-1469/10, although surprisingly no growth was observed after $2 \mathrm{~h}$ drying. Differences in results within replicates (indicated by numbers in parentheses within Table 1) and the lack of growth of Strain 98-1469/10 at $2 \mathrm{~h}$ may be due to the differences in the feathers themselves. Zoosporangia were more likely to attach to feathers with more barbs and a more downy appearance. Although every effort was made to maintain a similarity in the size and type of feathers used, the difference between the feathers may be a reason for differences in growth observed between the replicates.

Although these are in vitro studies, they highlight the necessity for more extensive studies using live avian hosts and more natural environments. If the findings of this study hold in nature, feathers (a source of keratin) are a possible means of transport of both chytrid zoosporangia and zoospores from one body of water to another. In coastal Queensland, Australia, the epidemic front of chytridiomycosis was calculated to travel at $100 \mathrm{~km} \mathrm{yr}^{-1}$ (Laurance et al. 1996) and there 
has been debate about how chytridiomycosis could have travelled so rapidly and traversed such large distances, particularly across barren areas of coastal Queensland to reach tropical regions (Laurance et al. 1996, Alford \& Richards 1997, Hero \& Gillespie 1997, Laurance et al. 1997). These papers all addressed an unknown pathogen that has since been identified as the chytrid organism. A number of different vectors were postulated (Laurance et al. 1996) such as migratory fish, the introduced cane toad Bufo marinus, aquatic birds, aquatic insects, vehicles or hikers. Observations made by researchers in Peru noted an unusual distribution of this pathogen (R. Schlute pers. comm.). Amphibian infections were found in areas too widely separated to allow for circular or linear distribution from one main centre of infection. They suggested this could be consistent with a wind-borne stage or the influence of migrating water birds (R. Schlute pers. comm.) and are considering investigating bird migration patterns and chytrid distribution patterns. Time spent out of water by a bird carrying the amphibian chytrid in droplets of water on its feathers, may determine the probability of translocation to a new site by that transmission event. It is likely that the longer a bird remains out of water, the less likely the chytrid fungus will be able to remain viable and thus be distributed.

The amphibian chytrid was tolerant to an extremely wide range of $\mathrm{pH}$. The only $\mathrm{pH}$ media in which it failed to grow or show activity were pH 3 and 4 (Table 3). In all other $\mathrm{pH}$ media tested, from $\mathrm{pH} 5$ through to $\mathrm{pH} 10$, a range of growth and activity were observed. The most advantageous $\mathrm{pH}$ range was between $\mathrm{pH} 6$ and

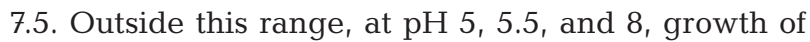
zoosporangia and activity by zoospores was observed, albeit slower than apparent within the preferred range. Our results agree with Pietrowski et al. (2004) in which optimal growth was at $\mathrm{pH} 6$ to 7 with minimal growth at $\mathrm{pH} 4$ to 5. In this study, at $\mathrm{pH} 9$ and $\mathrm{pH} 10$, there was some growth of zoosporangia and some activity of zoospores of both strains. However, this had ceased by $1 \mathrm{wk}$ post inoculation for both strains at $\mathrm{pH} 9$ and for Strain 98-1810/3 at pH 10. No active zoospores were observed at any time for Strain 98-1469/10 at $\mathrm{pH}$ 10. Zoospores remained viable for $1 \mathrm{wk}$ more at $\mathrm{pH} 9$ and 1 to 2 wk at $\mathrm{pH} 10$. These $\mathrm{pH}$ results agree with observations in Peñalara National Park in Central Spain (Bosch et al. 2001). Here it was reported that amphibian numbers had decreased in montane ponds where the $\mathrm{pH}$ had shown a rare change (together with levels of $\mathrm{Ca}^{2+}, \mathrm{Mg}^{2+}$ and $\mathrm{NO}_{3}^{-}$), increasing from a normally slightly acidic $\mathrm{pH}$ (stated as about $\mathrm{pH}$ 6) up to $\mathrm{pH}$ 9. Amphibians collected dead or found in terminal stages at these sites were observed by SEM and/or histological analysis to have chytridiomycosis. Amphib- ians inhabiting ponds of normal $\mathrm{pH}$ for that area appeared healthy and their numbers had not decreased.

This is the first demonstration of growth of Batrachochytrium dendrobatidis in soil. Between 17 and 21 generations would have been produced over the 12 wk growth observed from moist sand. No survival or growth occurred in the damp potting mixture ( $\mathrm{pH} 4.1$ ). The obvious difference between the 2 soil types was $\mathrm{pH}$, as moisture content was the same. However, a comparison of results of growth in water of a similar $\mathrm{pH}$ to the sand mixture clearly showed that there are other factors in addition to $\mathrm{pH}$ that influence chytrid survival. The similarity of $\mathrm{pH}$ of the sand mixture ( $\mathrm{pH}$ 5.8) to that of the sterile water $(\mathrm{pH} \mathrm{5.6),} \mathrm{but} \mathrm{the}$ significantly longer survival time, indicated that the sand mixture provided additional nutrients and/or more substrate for attachment. This enabled the fungus to survive for longer periods than in nutrientdeficient water alone. The ability of $B$. dendrobatidis to grow in a natural soil complete with soil microorganisms needs to be tested.

These results raised the question as to what percent moisture was required for survival by Batrachochytrium dendrobatidis. Johnson et al. (2003) showed that complete desiccation killed the fungus. Attempts were made during this study to clarify the moisture content parameters within which the chytrid may survive in vitro. Cultures containing sand, with moisture contents from 5 and $10 \%$ up to $60 \%$, in $10 \%$ intervals, were tested. However, these studies were inconclusive and gave variable results (results not shown). It was noted, however, that growth occurred in the sand mixture at $10 \%$ moisture content for one strain and $20 \%$ for the other strain. Growth was not necessarily observed for every higher percentage moisture content culture even though it has clearly been shown that both strains of $B$. dendrobatidis used in this study were able to survive for extended periods in water alone (100\% moisture) (Johnson \& Speare 2003). Therefore, these results were not considered reliable and this experiment needs to be repeated. It is suggested from these studies that moist soil is a risk as an environmental reservoir, and that $\mathrm{pH}$ is a critical factor in survival of the amphibian chytrid. We hypothesise that risk will vary with soil type, as soil types will vary in $\mathrm{pH}$ and moisture content.

Therefore, soil, either in the natural environment or used within the nursery industry, and feathers on water birds may pose a risk for the maintenance and spread of chytridiomycosis. Control strategies to prevent the spread of the amphibian chytrid must address these factors. The persistence and survival of Batrachochytrium dendrobatidis in damp soil environments, in the absence of amphibian hosts, has serious implica- 
tions. If this pathogen can survive for such lengths of time in the natural environment, in the presence of competitor microorganisms, it represents a fundamental problem. It constitutes an environmental source for continued spread from infected regions to naïve regions, possibly via the various vectors as suggested (Laurance et al. 1996, this study). It also presents a continued source of infection for amphibian species inhabiting an area, or for species introduced to repopulate an area. Control strategies may need to include prohibition of movement of river sand from chytrid-infected catchments to chytrid-free areas. Samples of water and soil moved with amphibians to new catchments and particularly chytrid-free areas should not be disposed of until they have been disinfected to kill B. dendrobatidis (Johnson et al. 2003). The real-time PCR test capable of detecting $B$. dendrobatidis in amphibians (Boyle et al. 2004) should be investigated for its suitability in detecting $B$. dendrobatidis in environmental samples to provide a tool for assessment of the amphibian chytrid-status of water sources and associated soils.

Acknowledgements. This study was funded by a grant from the National Heritage Trust, Department of Environment and Heritage, Australia, and from National Science Foundation Division of Biological Sciences - Integrated Research Challenges in Environmental Biology Grant IBN-99977063.

\section{LITERATURE CITED}

Alford RA, Richards SJ (1997) Lack of evidence for epidemic disease as an agent in the catastrophic decline of Australian rain forest frogs. Conserv Biol 11:2026-2029

Barr DJS (1980) An outline for the reclassification of the Chytridiales, and for a new order, the Spizellomycetales. Can J Bot 58:2380-2394

Berger L, Speare R, Daszak P, Green DE and 10 others (1998) Chytridiomycosis causes amphibian mortality associated with population declines in the rain forests of Australia and Central America. Proc Natl Acad Sci USA 95: 9031-9036

Berger L, Speare R, Hyatt A (1999) Chytrid fungi and amphibian declines. In: Campbell A (ed) Declines and disappearances of Australian frogs. Environment Australia, Canberra, p 23-33

Bosch J, Martinez-Solano I, Garcia-Paris M (2001) Evidence

Editorial responsibility: Peernel Zwart, Utrecht, The Netherlands of a chytrid fungus infection involved in the decline of the common midwife toad (Alytes obstetricans) in protected areas of central Spain. Biol Conserv 97:331-337

Boyle DG, Boyle DB, Olsen V, Morgan JAT, Hyatt AD (2004) Rapid quantitative detection of chytridiomycosis (Batrachochytrium dendrobatidis) in amphibian samples using real-time Taqman PCR assay. Dis Aquat Org 60:133-139

El-Hissy FT (1994) Oomycetes and Chytridiomycetes (Mastogimycotina) from water bodies in Tubingen region (Germany). J Basic Microbiol 2:67-76

Hero JM, Gillespie GR (1997) Epidemic disease and amphibian declines in Australia. Conserv Biol 11:1023-1025

Johnson ML, Speare R (2003) Survival of Batrachochytrium dendrobatidis in water: quarantine and disease control implications. Emerg Infect Dis 9:922-925

Johnson ML, Berger L, Philips L, Speare R (2003) Fungicidal effects of chemical disinfectants, UV light, desiccation and heat on the amphibian chytrid, Batrachochytrium dendrobatidis. Dis Aquat Org 57:255-260

Laurance WF, McDonald KR, Speare R (1996) Epidemic disease and the catastrophic decline of Australian rain forest frogs. Conserv Biol 10:406-413

Laurance WF, McDonald KR, Speare R (1997) In defense of the epidemic disease hypothesis. Conserv Biol 11:1030-1034

Longcore J, Pessier A, Nichols D (1999) Batrachochytrium dendrobatidis gen. et sp. nov., a chytrid pathogenic to amphibians. Mycologica 91:219-227

Mitchell RT, Deacon JW (1986) Selective accumulation of zoospores of Chytridiomycetes and Oomycetes on cellulose and chitin. Trans Br Mycol Soc 86:219-223

Mutschmann F, Berger L, Zwart P, Gaedicke C (2000) Chytridiomycosis in amphibians - first report in Europe. Berl Münch Tierärztl Wochenschr 113(10):380-383 (in German)

Pessier AP, Nichols DK, Longcore JE, Fuller MS (1999) Cutaneous chytridiomycosis in poison dart frogs (Dendrobates spp.) and White's tree frogs (Litoria caerulea). J Vet Diag Invest 11:194-199

Piotrowski JS, Annis SL, Longcore JF (2004) Physiology of Batrachochytrium dendrobatidis, a chytrid pathogen of amphibians. Mycologia 96(1):9-15

Speare R, Alford R, Aplin K, Berger L and 10 others (2001) Nomination for listing of amphibian chytridiomycosis as a key threatening process under the Environment Protection and Biodiversity Conservation Act 1999. In: Speare R (ed) Developing management strategies to control amphibian diseases: decreasing the risks due to communicable diseases. School of Public Health and Tropical Medicine, James Cook University, Townsville, p 185-196

Trigiano RN, Windham MT, Windham AS (2003) Plant pathology. Concepts and laboratory exercises. CRC Press, Boca Raton, FL

Waldmann B, van de Wolfshaar KE, Klena JD, Andjic V, Bishop P, Norman RJdeB (2001) Chytridiomycosis in New Zealand frogs. Surveillance 28(3):9-11

Submitted: September 15, 2004; Accepted: October 28, 2004 Proofs received from author(s): July 7, 2005 